\section{Effect of the Intensity and Spectral Quality of LED Light on Yield and Nitrate Accumulation in Vegetables}

\author{
Cinthia Nájera and Miguel Urrestarazu \\ Research Centre in Agri-Food Biotechnology (Centro de Investigación en \\ Biotecnología, CIAIMBITAL), University of Almeria, Almeria, Spain
}

Additional index words. indoor, healthy diet, leafy greens, lighting efficiency, photosynthesis, regulation

\begin{abstract}
At present, trends exist in the production of food for the benefit of human health. The negative effect of an excessive intake of nitrates accumulated in vegetables is well known, causing worldwide concern. Light plays an important role in the accumulation of this ion. The objective of this work was to evaluate the effect of light-emitting diode (LED) spectra used in artificial lighting for horticulture on the accumulation of nitrates in leafy and root vegetables compared with the effects with white LED lights. Two independent experiments were carried out in the culture chamber. In Expt. 1, six species of nitrate accumulators were used: arugula, spinach, lettuce, endive, radish, and beetroot. In Expt. 2, four lettuce cultivars were used. In both experiments, the treatments were two spectra-T1 $=$ AP67 Valoya ${ }^{\circledR}$ and the control $($ T0 $)=$ white Roblan $^{\circledR}$-at two illumination intensities [high $(\mathrm{H})$ and low $(\mathrm{L})$ ] with a 16/8-hour (day/night) photoperiod. The fresh biomass and the concentration of nitrates were measured at 35 days of treatment posttransplantation. An important and significant increase of $50 \%$ of the mean fresh weight was obtained in all the species when the light intensity increased. Except for spinach in the low-intensity treatment, all nitrate content values were less than the maximum limits of European regulation. The nitrate content generally decreased with increasing intensity, and this benefit was greater in the $\mathrm{T} 1$ treatment. T0 showed a reduction in the nitrate content compared with $T 1$ in only one case, which was the $H$ in beetroot. A large and significant reduction was observed in the nitrate content in $\mathrm{T} 1$. For $\mathrm{L}$ in Expt. 1, the nitrate decrease was $18 \%$, whereas for $\mathrm{H}$, it was $35 \%$. In Expt. 2, the decrease in the nitrate content was $10 \%$ for $L$ and $21 \%$ for $H$. A greater benefit was derived when using the photosynthetic spectrum in the growing chambers under low light intensity.
\end{abstract}

The concentration of nitrate accumulated in plants depends on the plant variety or cultivar (Álvaro et al., 2016; European Food Safety Authority, 2008; Urrestarazu, et al., 1998), the time of year in which the plant is grown (Carrasco et al., 2006), the irradiation it receives (Blom-Zandstra, 1989; Roorda, 1984), the cultivation system used (Carrasco et al., 2006; Nicola et al., 2007), and the management practices and the nutritive ions applied (Fontana and Nicola, 2009; Urrestarazu et al., 1998). Nitrate is found in vegetables, fruits, meats, fish, grains, and in several products that are part of the basic diet of human beings (Gürkan and Altunay, 2018). According to the Agency for Toxic Substances and Disease Registry (2015), nitrate is a source of carcinogenic nitrosamines via nitrites (Addiscott, 2006; Cometti and Furlani, 2009), which can seriously compromise human health (Hord, 2011). Moreover, the consumption of nitrate-accumulating vegetables in children younger than 6 years is especially worrisome according to the Euro-

Received for publication 5 June 2019. Accepted for publication 24 June 2019.

M.U. is the corresponding author. E-mail: mgavilan@ ual.es. pean Food Safety Authority (2010), because $75 \%$ of the nitrates consumed are supplied by vegetables (Hill, 1990).

Arugula, spinach, lettuce, and escarole are vegetables that are eaten raw, are species with a tendency to accumulate high concentrations in the leaves and ribs, and have no restrictions on daily intake (Cometti et al., 2011; Gent, 2016). Beetroot and radish are also considered root vegetable sources of 2008).

The species considered in this work are widely cultivated in Spain, according to statistical data from the Food and Agriculture Organization and the Spanish Ministry of Agriculture, Fisheries and Food. These crops have made Spain one of the five leading countries in terms of production over a period of 20 years (1993-2013). The cultivation areas are $3686,34,862,33,168,2200$, and 282 ha for spinach, lettuce, beet, escarole, and radish, respectively, with a corresponding production of $67,000,930,000,3,240,000$, $59,000,000$, and $5000 \mathrm{t}$, respectively (Food and Agriculture Organization, FAOSTAT, 2016; Ministerio de Agricultura, Pesca y Alimentación, 2016).

The presence of high levels of nitrate in vegetables, especially in leaves and roots, has nitrates (European Food Safety Authority, been well known for decades (e.g., Carrasco et al., 2006; Chan, 2011; Corré and Breimer, 1979; Hsu et al., 2009; Sanchez et al., 2005; Santamaria, 2006) and has been reported more recently (Bantis et al., 2018; Colla et al., 2018; Wojciechowska et al., 2015). As a result, since 2002, the European Union has established maximum levels for certain contaminants in food. In 2011, the European Commission updated the maximum levels as follows: 5000 and $4000 \mathrm{mg} \mathrm{NO}_{3}{ }^{-} / \mathrm{kg}$ fresh weight for lettuce harvested in winter and spring, respectively; 3500 and $2000 \mathrm{mg}$ $\mathrm{NO}_{3}{ }^{-} / \mathrm{kg}$ fresh weight for spinach harvested in winter and spring, respectively; 7000 and $6000 \mathrm{mg} \mathrm{NO}_{3}{ }^{-} / \mathrm{kg}$ fresh weight for arugula, which presents the highest levels of nitrate, in winter and summer, respectively; and $2500 \mathrm{mg} \mathrm{NO}{ }_{3}^{-} / \mathrm{kg}$ fresh weight for iceberg lettuce (European Commission, 2002, 2006, 2011). In 2008, the EFSA published a reference report of nitrates in some vegetables as follows: escarole, with a mean of $523 \mathrm{mg}$ $\mathrm{NO}_{3}{ }^{-} / \mathrm{kg}$ fresh weight; radish, with $967 \mathrm{mg}$ $\mathrm{NO}_{3}^{-} / \mathrm{kg}$ fresh weight; and beetroot, with $1379 \mathrm{mg} \mathrm{NO}{ }_{3}^{-} / \mathrm{kg}$ fresh weight (European Food Safety Authority, 2008).

Plants grown hydroponically show greater nitrate levels compared with those grown in conventional systems (Beninni et al, 2002), even though they are cultivated with a controlled supplemental lighting system (Lin et al., 2013). Despite the improved cultivation practices and the current technologies associated with a strict application of these regulations, in certain regions of the European Union, it is not possible to achieve nitrate levels in lettuce and spinach that are less than the current maximum limits (European Commission, 2011).

Researchers agree on a close relationship between the accumulation of nitrate in vegetables and the intensity of light (Chadjaa et al., 1995; Cometti et al., 2011; Fukuda et al., 1999; He et al., 2015; Ohashi et al., 2007; Steingröver et al., 1986), because photosynthesis causes the uptake and assimilation of nitrates in vegetables (Cavaiuolo and Ferrante, 2014).

In recent years, effective techniques have been developed for the growth and morphological development of plants, especially those grown in a soilless system and in closed and controlled structures under LED lights (Johkan et al., 2012; Urrestarazu et al., 2016). This advance in agriculture can be beneficial for the reduction of nitrate levels in plants that accumulate the most and, above all, in plants that are most consumed in the world. Some work relates the content of nitrates in leaves and the quality of fluorescent lamps (e.g., Deng et al., 2000; Ohashi et al., 2007; Seifu, 2017), and researchers have studied the decrease of nitrate reductase in produce grown in the dark (Riens and Walter, 1991), but few studies have been conducted on the quality of LED spectra as a beneficial tool for safer food (Lin et al., 2013; Nájera et al., 2018; Wojciechowska et al., 2015), especially for hydroponic crops. Therefore, the objective of this work was to evaluate how 
LED spectra used in artificial lighting for horticulture affect the accumulation of nitrates in leafy and root vegetables compared with the effect of white LED lights.

\section{Materials and Methods}

The experiment was carried out in a $10 \times$ 2.5-m controlled culture chamber located in the experimental field of practice of the University of Almeria in the province of Almeria in southern Spain (lat. 36 $49^{\prime} 38.1^{\prime \prime} \mathrm{N}$, long. $2^{\circ} 24^{\prime} 19.3^{\prime \prime} \mathrm{W}$ ).

LED treatments. White LED lamps (L18 T8 Roblan ${ }^{\circledR}$, Toledo, Spain) were used as a control (T0) and L18 T8 AP67 from (Valoya ${ }^{\circledR}$, Helsinki, Finland) was used as the spectrum to be evaluated (T1). Each treatment had two light intensities: T0 $=85$ and $117 \mu \mathrm{mol} \cdot \mathrm{m}^{-2} \cdot \mathrm{s}^{-1}$, which were low and high intensities consisting of four and six lamps per square meter, respectively; and $\mathrm{T} 1=52$ and $95 \mu \mathrm{mol} \cdot \mathrm{m}^{-2} \cdot \mathrm{s}^{-1}$, which were low and high, respectively. Each lamp was $120 \mathrm{~cm}$ in length. Spectral specifications, quantitative light values, photon flux density (measured in micromoles per square meter per second) and illuminance (measured in lux) are described in a previous study (Urrestarazu et al., 2016). Photoperiods were $16 / 8 \mathrm{~h}$ (day/night) at a temperature of 28 to $18{ }^{\circ} \mathrm{C}$ (day/night) and relative humidity of $85 \%$ to $80 \%$.

Experimentation and plant material. The work was divided into two experiments with different plant species. For Expt. 1, six species were used: arugula (Eruca sativa Mill. cv. Enza), spinach (Spinacia oleracea L. cv. Esmer), lettuce (Lactuca sativa L. cv. Maravilla de verano), escarole (Cichorium intybus L. cv. Cabello de angel), radish (Raphanus sativus L. cv. Redondo rojo), and beetroot (Beta vulgaris L. cv. Detroit 2). For Expt. 2, four varieties of lettuce (Lactuca sativa L.) were used: Batavia (cv. Maravilla de verano), cogollo (cv. Astorga), romaine (cv. Cervantes), and iceberg (cv. California).

Seedlings were transplanted at the stage of four true leaves in $0.6-\mathrm{L}$ pots filled with coconut fiber and then placed in the culture chamber and "fertirrigated" with a standard solution recommended by Sonneveld and Straver (1994).

Harvest. Plant biomass was measured at $35 \mathrm{~d}$ after transplantation, stored cold until laboratory analysis, and subsequently taken to the laboratory in zipped plastic bags inside an isothermal container at a controlled temperature. Only the edible parts were analyzed. Fresh weight was determined using an OHAUS Adventurer ${ }^{\circledR}$ Analytical Precision Balance (Atkinson, $\mathrm{NH}$ ) with precision to four-tenths of a gram.

Nitrate analysis. The nitrate content was determined by the method described by Urrestarazu et al. (1998), using ion chromatography, and as described by Chang and Chang (2014), using a LAQUA Twin Nitrate $\left(\mathrm{NO}_{3}{ }^{-}\right)$rapid response digital meter (LAQUA Twin Nitrate Meter, Spectrum Technologies, Inc.). Measurements for arugula, spinach, lettuce, and escarole were obtained from the sap of the leaves. For radish and beetroot, the bulb or root was crushed, and the sap and juice obtained were stored in 2-mL microcentrifuge tubes until analysis.

Statistical analysis. The experimental design was a randomized complete block design, with four repetitions for four treatments and five plants per repetition (Montgomery, 2004). The mean data were analyzed at different levels of significance. The data were subjected to analysis of variance and their means were compared by Tukey's test using Statgraphics Centurion $^{\circledR}$ (version 16.1.15; Warrenton, VA) (Statgraphics Centurion, 2018). Some data were analyzed by means of Student's $t$ test in Excel 2016.

\section{Results and Discussion}

The average increase in fresh weight was $50 \%$ in all species evaluated for all spectra (Table 1). Arugula had the greatest percentage of growth in fresh weight $(66 \%)$ when the light intensity was increased and white LED lighting was used. Escarole and radish obtained the greatest benefit (both 65\%) when cultivated at high intensity, with the T1 treatment corresponding to the photosynthetic spectrum. However, plant growth in the $\mathrm{T} 1$ treatment was $6 \%$ greater than for those plants cultivated in T0. An improvement in productivity relative to $\mathrm{T} 0$ was observed with $\mathrm{T} 1$ at low intensity; the fresh weight of the species increased between $6 \%$ and $58 \%$, with arugula presenting the greatest vegetative growth. In the case of plants cultivated with high light intensity in T1, an average increase of $20 \%$ was seen compared with those cultivated under T0, in which the fresh weight of radish increased by $45 \%$. A change in spectrum and intensity was shown previously to improve the parameters of vegetative growth by Yang and Park (2015); by Samuoliene et al. (2011) in radish; by Urrestarazu et al. (2016) in lettuce, to- mato, and pepper; and by Burattini et al. (2017) in spinach. T1 produced a significant increase in fresh weight that varied between $12 \%$ for lettuce and $45 \%$ for radish. Working in similar conditions, Urrestarazu et al. (2016) found that the vegetative growth doubles and, in some cases, can be greater than 200\%, whereas Samuoliene et al. (2011) achieved significant growth $(90 \%$ more) in radish.

The behavior of the lettuce varieties (Table 2) in terms of intensity (low vs. high) and the specific spectrum (T0 vs. T1) was very similar to that of the other vegetables. The California cultivar showed greater growth than the rest of the cultivars when cultivated with increasing light intensity of white LED lighting $(82 \%)$ and LED T1 (72\%). Under T1, the Maravilla de verano cultivar similarly demonstrated an increase in fresh weight (by 72\%) with high light intensity. When comparing the light spectra, the Astorga cultivar showed the greatest increase compared with the other cultivars, both at low and high light intensity $(60 \%$ and $46 \%$, respectively) when cultivated under $\mathrm{T} 1$.

\section{Effect of nitrate content on vegetable species: Comparison with mean values and legal maximum limits}

Figure 1 shows the resulting mean values of the nitrate content. In arugula and lettuce, nitrate levels of $16 \%$ and $60 \%$ less, respectively, than the legal limits were recorded (European Commission, 2006). In addition, the spinach cultivated under high light intensity yielded lower values (54\% lower). For radish and beetroot (root vegetables), the mean content values were $13 \%$ and $10 \%$ less, respectively, than those reported by the European Food Safety Authority (2008). The nitrate content in spinach grown under highintensity light recorded a significantly lower value $(45 \%)$ than the mean values reported from the United States (Sanchez et al., 2005); for the rest of the vegetables (arugula, spinach, lettuce, and escarole), our values were greater.

Table 1. Effect of the light intensity and spectral composition on total weight of edible part ( $\mathrm{g} / \mathrm{plant}$ fresh weight) of six vegetables.

\begin{tabular}{|c|c|c|c|c|}
\hline Plant & Intensity & T0 & $\mathrm{T} 1$ & $P$ value \\
\hline \multirow[t]{3}{*}{ Arugula cv. Enza } & $\mathrm{L}$ & 5.5 & 13.4 & $* * *$ \\
\hline & $\mathrm{H}$ & 16.5 & 28.1 & $* * *$ \\
\hline & $P$ value & $* * *$ & $* * *$ & \\
\hline \multirow[t]{3}{*}{ Spinach cv. Esmer } & $\mathrm{L}$ & 7.1 & 8.8 & $* *$ \\
\hline & $\mathrm{H}$ & 12.3 & 14.7 & $* * *$ \\
\hline & $P$ value & $* * *$ & $* * *$ & \\
\hline \multirow[t]{3}{*}{ Lettuce cv. Maravilla de verano } & $\mathrm{L}$ & 29.6 & 33.2 & $* *$ \\
\hline & $\mathrm{H}$ & 38.7 & 50.2 & $* *$ \\
\hline & $P$ value & $*$ & $* * *$ & \\
\hline \multirow[t]{3}{*}{ Escarole cv. Cabello de ángel } & $\mathrm{L}$ & 11.3 & 12.1 & NS \\
\hline & $\mathrm{H}$ & 26.8 & 34.7 & $*$ \\
\hline & $P$ value & $* * *$ & $* * *$ & \\
\hline \multirow[t]{3}{*}{ Radish cv. Redondo rojo } & $\mathrm{L}$ & 3.5 & 2.9 & NS \\
\hline & $\mathrm{H}$ & 4.5 & 8.3 & $* * *$ \\
\hline & $P$ value & $*$ & $* * *$ & \\
\hline \multirow[t]{3}{*}{ Beetroot cv. Detroit 2} & $\mathrm{~L}$ & 22.4 & 36.5 & $*$ \\
\hline & $\mathrm{H}$ & 53.2 & 70.6 & $*$ \\
\hline & $P$ value & $* * *$ & $* * *$ & \\
\hline
\end{tabular}

$\mathrm{L}$ and $\mathrm{H}$ represent 4 and 6 lamps $/ \mathrm{m}^{2}$, respectively.

T0 $=$ L18 T8 Roblan ${ }^{\circledR}$, T1 = L18 AP67 Valoya ${ }^{(}$

NS, $* * *, * * *$ Nonsignificant or significant at $P \leq 0.05,0.01$, or 0.001 , respectively. $\mathrm{n}=4$. 
Table 2. Effect of the light intensity and spectral composition on total weight of edible part ( $\mathrm{g} / \mathrm{plant}$ fresh weight) of four lettuce varieties.

\begin{tabular}{llccc}
\hline Variety & Intensity & T0 & T1 & $P$ value \\
\hline Batavia cv. Maravilla de verano & $\mathrm{L}$ & 14.5 & 21.0 & $* *$ \\
& $\mathrm{H}$ & 50.9 & 76.3 & $* *$ \\
Cogollo cv. Astorga & $P$ value & $* * *$ & $* * *$ & $* * *$ \\
& $\mathrm{~L}$ & 6.5 & 16.6 & $* * *$ \\
Romane cv. Cervantes & $\mathrm{H}$ & 13.8 & 25.8 & $* * *$ \\
& $P$ value & $* * *$ & $* *$ & $* * *$ \\
Iceberg cv. California & $\mathrm{L}$ & 16.9 & 29.2 & \\
& $\mathrm{H}$ & 49.7 & 70.3 & NS \\
& $P$ value & $* * *$ & $* * *$ & \\
\hline
\end{tabular}

$\mathrm{L}$ and $\mathrm{H}$ represent 4 and 6 lamps $/ \mathrm{m}^{2}$, respectively.

$\mathrm{T} 0=\mathrm{L} 18$ T8 Roblan ${ }^{\circledR}, \mathrm{T} 1=$ L18 AP67 Valoya ${ }^{\circledR}$.

Ns, ${ }^{*}, * *, * * *$ Nonsignificant or significant at $P \leq 0.05,0.01$, or 0.001 , respectively. $\mathrm{n}=4$.
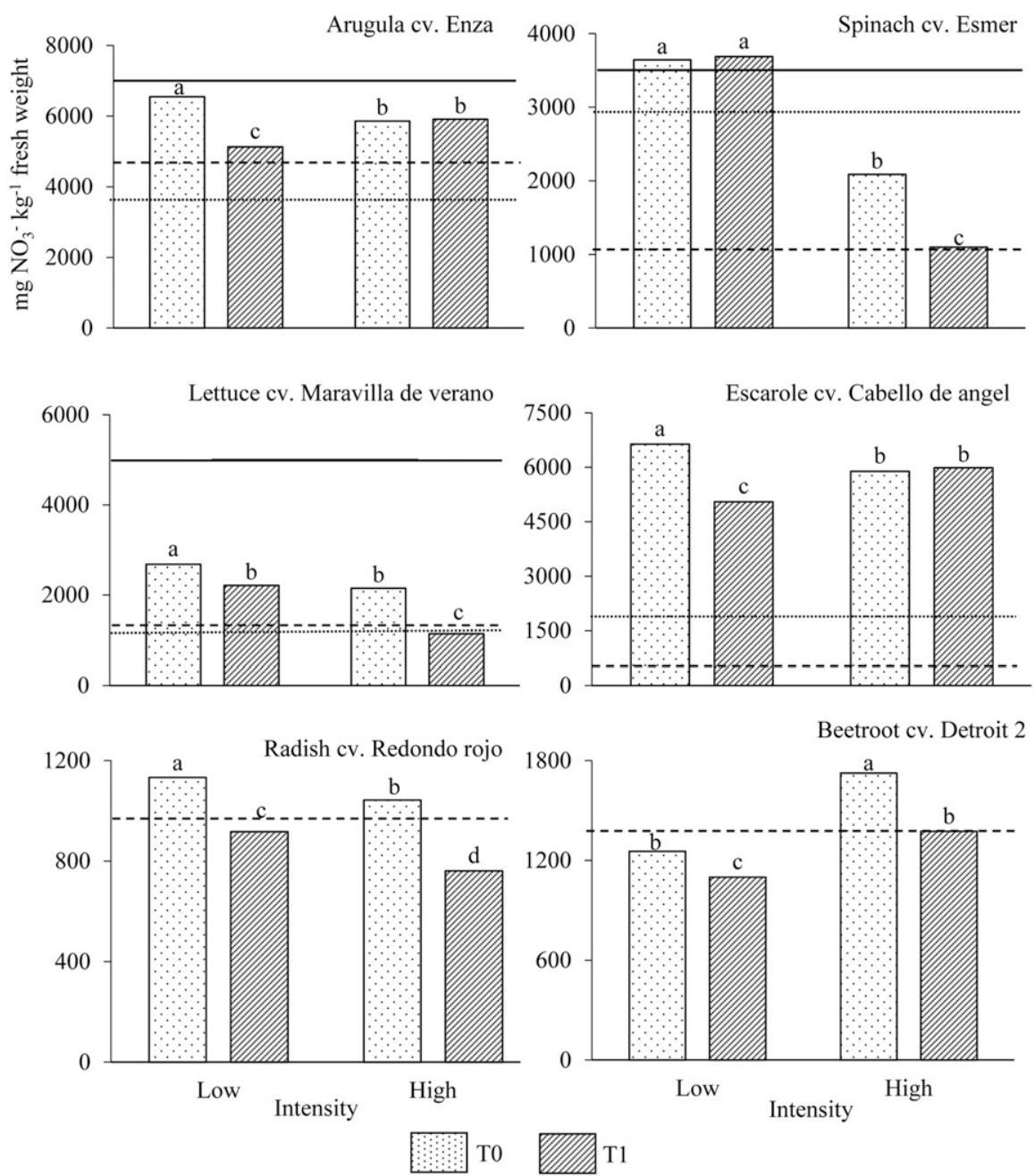

Maximum levels in winter by Regulation Co
Mean by European Food Safety Authority
High) of six vegetables. T0, L18 T8 Robla
significant differences between spectra by Tuk (2005) in USA.
ffect of light intensity on nitrate content

A decrease in the nitrate content was recorded with a lower irradiation intensity for the case of the T1 spectrum in beetroot
(24\%), escarole $(15 \%)$, and arugula $(13 \%)$ Moreover, in general, a decrease in the nitrate content was recorded with greater irradiation. The greatest decrease in nitrates resulting from an increase in irradiation intensity was seen in spinach and was as much as $70 \%$ in the case of T1. Similar results have been obtained in different conditions, with leaves of barley, wheat, corn, and beans (Canvin and Atkins, 1974); spinach and greenhouse lettuce (Gaudreau et al., 1995; Steingröver et al., 1986); lettuce and spinach under supplementary light (Chadjaa et al., 1995; Proietti et al., 2004); and, more recently, in lettuce crops in greenhouses (e.g., Fallovo et al., 2009; Gent, 2014) and Brassica in aeroponics (Fu et al., 2017; He et al., 2015)and all these plants obtained lower concentrations of nitrates with greater irradiance. However, Novo et al. (2008) found no significant difference in lettuce and spinach grown with $18 \%$ and $50 \%$ shade in the greenhouse. This result means that the limits of the current legislation in winter are greater than those for summer, when greater irradiation occurs (Fig. 1). This decrease in nitrate content may be because, with high light irradiation, some enzymes involved in the metabolism of nitrates to amino acids [glutamine synthetase (GS) and glutamate synthase (GOGAT)] are stimulated, and a nonessential amino acid is inhibited [asparagine synthetase (AS)] (Zhang et al., 2018), favoring the assimilation of nitrogen into carbon-rich compounds (glutamine and glutamate). Conversely, in low light, GS and GOGAT are inhibited, and AS, which is a compound rich in nitrogen and stabilizes nitrate for transport or storage, is stimulated.

In low lighting, beetroot obtained the lowest nitrate content in the product that could be used, unlike the rest of the leafy vegetables and the radishes tested. The reason for this was probably because this plant stores nitrates in the roots before transporting it to the leaves. There are few works on the variation of nitrate content in radish with which to compare. Postharvest, Lee et al. (2017) observed a decrease in the concentration of secondary metabolites containing nitrogen (glucosinolates) during cold storage from 0 to 8 weeks in darkness.

\section{Effect of spectrum on nitrate content on vegetable species}

In low light treatments, the nitrate content was less in the T1 spectrum (mean, 19\%), with the exception of spinach. In the highintensity $\mathrm{T} 1$ treatments, a decrease in nitrate content was recorded for lettuce and spinach $(47 \%)$, radish $(27 \%)$, and beetroot $(20 \%)$. Ohashi et al. (2007) obtained 64\% less nitrate in lettuce and spinach grown under red or blue fluorescent light vs. those cultivated in white light. Samuoliene et al. (2009) - in marjoram, lettuce, and green onionobtained less nitrate under LED light vs. HPS light. A recent study reported that spectra of the same intensity increases the lycopene content in tomato (Nájera et al., 2018) or contributes to better growth in lettuce, pepper, and tomato plants (Urrestarazu et al., 2016) or pomegranate plants (Bantis et al., 2018). Therefore, the effect of T1 is very significant in decreasing 
nitrate content in vegetables, modifying the composition of some enzymes inside the plant when exposed to different spectra.

\section{Effect of nitrate content in intraspecific lettuce varieties}

Comparison with the mean values (European and U.S.) and legal maximum limits. Figure 2 shows the nitrate content results of Expt. 2 for lettuce varieties. The nitrate content data of the iceberg cv. California were less than those for the other three varieties. Although mean values of $16 \%$ were found for the California cultivar, the differences between the observed values and legal limits for the other varieties were much greater $(51 \%)$. All the nitrate content values were greater than those reported by the European Food Safety Authority (2008) and the mean data in the United States (Sanchez et al., 2005).

Effect of light intensity on nitrate content in intraspecific lettuce varieties. All our data were less than the legal limits of 5000 $\mathrm{mg} \cdot \mathrm{kg}^{-1}\left(2500 \mathrm{mg} \cdot \mathrm{kg}^{-1}\right.$ for the iceberg variety), even at low light intensity $\left(50 \mu \mathrm{mol} \cdot \mathrm{m}^{-2}\right.$ $\left.\cdot \mathrm{s}^{-1}\right)$. With the exception of the Astorga cultivar, a significant average decrease of $22 \%$ in nitrate content was obtained at greater irradiation. At low intensity, only the lettuce cultivar Astorga showed a nitrate decrease (17\%) when cultivated under the T1 treatment. Novo et al. (2008) found values at midlatitudes (high irradiation) that were greater than $3000 \mathrm{mg} \cdot \mathrm{kg}^{-1}$ when $18 \%$ shading was applied in Brazilian greenhouses. We agree with others that lower nitrate content occurs at high irradiation. For example, Cometti et al. (2011) obtained greater accumulation of nitrates in shoots of the lettuce cultivar Vera with $80 \%$ shading in the greenhouse $\left(118 \mu \mathrm{mol} \cdot \mathrm{m}^{-2} \cdot \mathrm{s}^{-1}\right)$. The physiological explanation of the relationship between irradiation intensity and the lower nitrate content has already been described extensively in recent decades. Nitrate reductase is activated by illumination and therefore decreases the accumulation of nitrate (e.g., Blom-Zandstra et al., 1988; Huber et al., 1992).

Effect of the spectrum on nitrate content in intraspecific lettuce varieties. The nitrate content was less with the T1 treatment, with the exception of the cultivar Astorga under high-intensity light and the cultivar Cervantes under low-intensity light, for which no significant decrease was observed in nitrate content in $\mathrm{T} 1$ with respect to $\mathrm{T} 0$. The greatest reduction (by $24 \%$ ) in nitrate content with the T1 spectrum was recorded at the greatest intensity $\left(95 \mu \mathrm{mol} \cdot \mathrm{m}^{-2} \cdot \mathrm{s}^{-1}\right)$ for the Summer Wonder and California cultivars, whereas a smaller reduction (11\%) was found in the cultivar Astorga at low light intensity under T1. Some specific responses regarding the type of spectrum and nitrate content in leaves have been reported, along with rice cultivation, for which Deng et al. (2000) used blue, red, and white fluorescent lamps and measured nitrate content by the primary assimilation of nitrogen. They observed greater nitrate levels in plants grown for 2
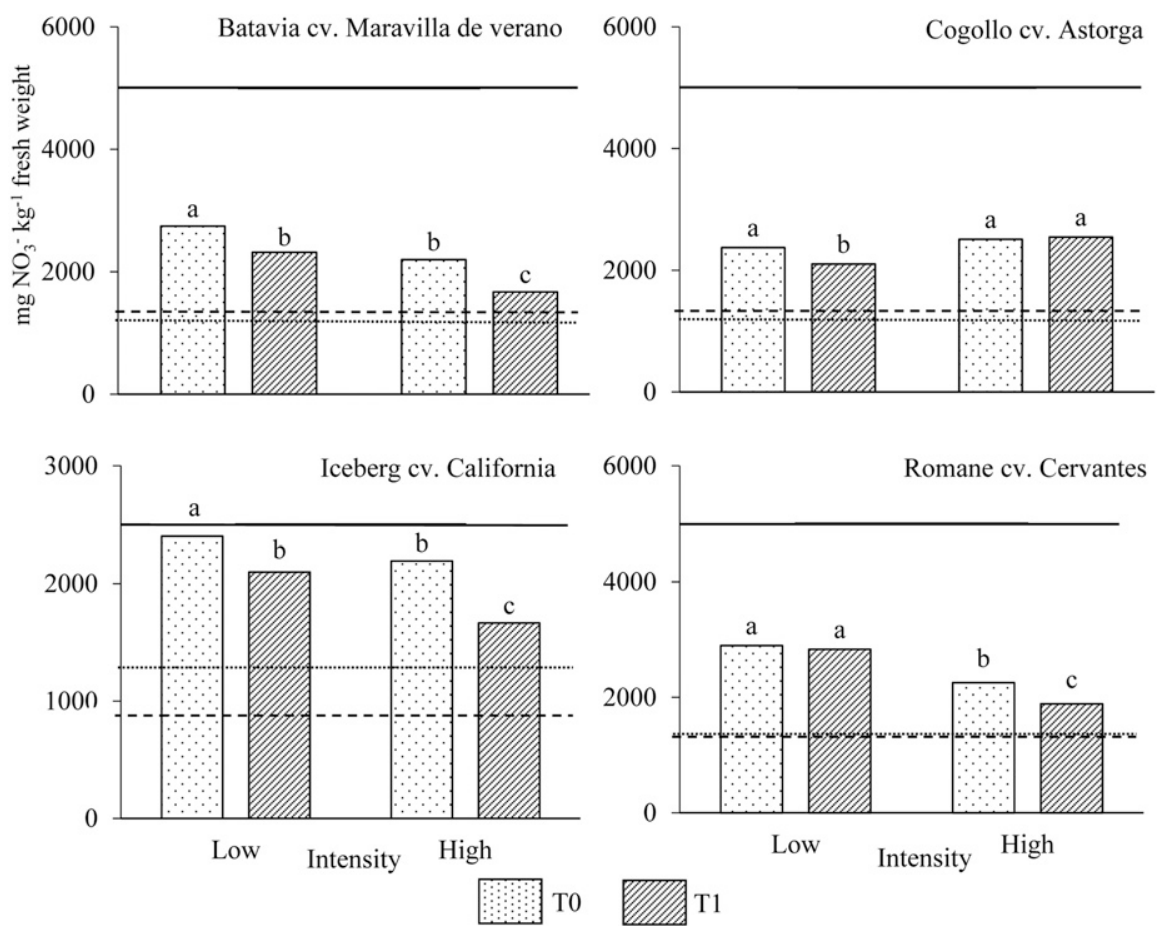

- Maximum levels in winter by Regulation Commission, Official Joun
- Mean by European Food Safety Authority (2008) in Europe.
............... Mean by Sanchez et al. (2005) in USA.

Fig. 2. Nitrate content according to quality spectra in two LED-light intensities (Low and High) of four lettuce varieties. T0, L18 T8 Roblan ${ }^{\circledR}$; T1, L18 AP67 Valoya ${ }^{\circledR}$. Different letters indicate significant differences between spectra by Tukey's test $(P \leq 0.05, \mathrm{n}=4)$.

to $6 \mathrm{~h}$ with pure blue light. Ohashi et al. (2007) obtained $63 \%$ less nitrate content in lettuce cultivated with fluorescent red lights at a photoperiod of $12 \mathrm{~h}$ and an intensity of $300 \mu \mathrm{mol} \cdot \mathrm{m}^{-2} \cdot \mathrm{s}^{-1}$. Lin et al. (2013), in works aimed at quality studies of hydroponic lettuce (var. Capitata), used the following lighting treatments: 1) a combination of red and blue LEDs; 2) blue, red, and white LEDs; and 3) fluorescent lamps. The lowest concentration of nitrates in leaves was obtained by the LED treatment combining the three spectra. Probably, the combination LED spectra used in their most efficient treatments was similar to the spectra we used (T1). Recently, postharvest (Seifu, 2017), fluorescent lamps have been used to delay the accumulation of nitrate content in lettuce collected for different supermarkets for transformation into minimally processed produce.

\section{Conclusion}

Regarding performance for the two spectra, doubling the light intensity leads to a significant improvement in productivity for all species, with values varying between $30 \%$ and $60 \%$. The increase in light intensity had an important effect on the growth of all species studied, and in one species this effect varied between $35 \%$ and $85 \%$.

The specific spectrum treatment at a low intensity and high intensity resulted in a significant decrease in the nitrate content ( $18 \%$ and $35 \%$, respectively) for the species. For the varieties of lettuce, a significant decrease in nitrate content of $10 \%$ and $21 \%$ was observed at low and high light intensities, respectively. This same spectrum also showed the greatest decreases in nitrate content from low to high intensity of $45 \%$ and $27 \%$ for all species and within one of them, respectively. Escarole was the species with the greatest decrease in nitrate levels at low intensity $(23 \%)$ under a photosynthetic spectrum; at high intensity, spinach contained $47 \%$ less nitrate than spinach grown under white LEDs.

\section{Literature Cited}

Addiscott, T. 2006. Is it nitrate that threatens life or the scare about nitrate? J. Sci. Food Agr. 86:2005-2009.

Álvaro, J.A., S. Carrasco, and M. Urrestarazu. 2016. Effect of the organic production system and seasonality on nitrate content in vegetables from Spanish supermarkets. Sylwan 160:348-363.

Agency for Toxic Substances and Disease Registry. 2015. Public health summary: Nitrate and nitrite. Division of Toxicology and Health Sciences. 10 Jan. 2017. <https://www.atsdr.cdc.gov/es/phs/ es_phs204.pdf $>$.

Bantis, F., K. Karamanoli, A. Ainalidou, K. Radoglou, and H. Constantinidou. 2018. Light emitting diodes (LEDs) affect morphological, physiological and phytochemical characteristics of pomegranate seedlings. Scientia Hort. 234:267-274.

Beninni, E., H. Takahashi, C. Neves, and I. Fonseca. 2002. Teor de nitrato em alface cultivada em sistemas hidropônico e convencional. Hort Bras. 20:183-186. 
Blom-Zandstra, M. 1989. Nitrate accumulation in vegetables and its relationship to quality. Ann. Appl. Biol. 115:39-55.

Blom-Zandstra, M., J.E.M. Lampe, and H.M. Ammerlaan. 1988. C and $\mathrm{N}$ utilization of two lettuce genotypes during growth under nonvarying light conditions and after changing the light intensity. Physiol. Plant. 74:147-152.

Burattini, C., B. Mattoni, and F. Bisegna. 2017. The impact of spectral composition of white LEDs on spinach (Spinacia oleracea) growth and development. Energies 10:1383.

Canvin, D.T. and C.A. Atkins. 1974. Nitrate, nitrite and ammonia assimilation by leaves: Effect of light, carbon dioxide and oxygen. Planta 116:207-224.

Carrasco, G., J. Tapia, and M. Urrestarazu. 2006. Nitrate content in lettuces grown in hydroponic systems. Idesia 24:25-30.

Cavaiuolo, M. and A. Ferrante. 2014. Nitrates and glucosinolates as strong determinants of the nutritional quality in rocket leafy salads. $\mathrm{Nu}-$ trients 6:1519-1538.

Chadjaa, H., L.P. Vezina, S. Dubé, and A. Gosselin. 1995. Effects of supplementary lighting on growth and primary nitrogen metabolism of greenhouse lamb's lettuce and spinach. HortScience 30:883-884.

Chan, T.Y. 2011. Vegetable-borne nitrate and nitrite and the risk of methaemoglobinaemia. Toxicol. Lett. 200:107-108.

Chang, C.L. and K.P. Chang. 2014. The growth response of leaf lettuce at different stages to multiple wavelength-band light-emitting diode lighting. Scientia Hort. 179:78-84.

Colla, G., H.J. Kim, M.C. Kyriacou, and Y. Rouphael. 2018. Nitrate in fruits and vegetables. Scientia Hort. 237:221-238.

Cometti, N.N. and P.R. Furlani. 2009. Hidroponia e segurança alimentar, p. 517-528. In: A. Ferreira, A.B.P. Lima, F.P. Matta, J.A.T. Amaral, J.C. Lopes, J.E.M. Pezzopane, M.F.S. Ferreira, R.A. Polanczyk, and T.C.B. Soares (eds.). Tópicos especiais em produção vegetal. 1st ed. Centro de Ciências Agrárias, Alegre-ES, Brasil.

Cometti, N.N., M.Q. Martins, C.A. Bremenkamp, and J.A. Nunes. 2011. Nitrate concentration in lettuce leaves depending on photosynthetic photon flux and nitrate concentration in the nutrient solution. Hort. Bras. 29:548-553.

Corré, W.J. and T. Breimer. 1979. Nitrate and nitrite in vegetables. Centre for Agricultural Publishing and Documentation 39, Wageningen, the Netherlands.

Deng, J.M., J.H. Bin, and R.C. Pan. 2000. Effect of light quality on the primary nitrogen assimilation of rice (Oryza sativa L.) seedlings. Acta Bot. Sin. 42:234-238.

European Commission. 2002. Regulation no. 563/ 2002 of 2 Apr. 2002 amending regulation (EC) no. 466/2001: Setting maximum levels for certain contaminants in foodstuffs. OJ. L. 86:5-6. 10 Dec. 2016. <https://publications.europa.eu/ en/publication-detail/-/publication/6bf91c080654-4c10-8a24-23473f1210e8/language-en>.

European Commission. 2006. Regulation no. 1881/ 2006 of 19 Dec. 2006: Setting maximum levels for certain contaminants in foodstuffs. OJ. L. 2006 364:5-24. 10 Dec. 2016. <https://eurlex.europa.eu/legal-content/EN/ALL/?uri=celex \%3A32006R1881>.

European Commission. 2011. Regulation no. 1258/ 2011 of 2 Dec. 2011 amending regulation no. $1881 / 2006$ as regards maximum levels for nitrates in foodstuffs. OJ. L. 2011 320:15-17. 10 Dec. 2016. <https://www.fsai.ie/uploadedFiles/ Reg1258_2011.pdf $>$.

European Food Safety Authority (EFSA). 2008. Nitrate in vegetables: Scientific opinion of the panel on contaminants in the food chain. 689:179. 10 Dec. 2016 . <http://www.efsa.europa.eu/ sites/default/files/scientific_output/files/main_ documents/689.pdf $>$.

European Food Safety Authority (EFSA). 2010. Scientific Opinion. Statement on possible public health risks for infants and young children from the presence of nitrates in leafy vegetables. EFSA J. 8:1935. 10 Jul. 2017. <https:// www.efsa.europa.eu/en/efsajournal/pub/ $1935>$.

Fallovo, C., Y. Rouphael, E. Rea, A. Battistelli, and G. Colla. 2009. Nutrient solution concentration and growing season affect yield and quality of Lactuca sativa L. var. acephala in floating raft culture. J. Sci. Food Agr. 89:1682-1689.

Food and Agriculture Organization, FAOSTAT. 2016. Details of spinach, lettuce, radish, arugula, beetroot and escarole, from 2013 to 2016 24 Feb. 2017. <http://www.fao.org/faostat/en/ \#data/QC>.

Fontana, E. and S. Nicola. 2009. Traditional and soilless culture systems to produce corn salad (Valerianella oliotoria L.) and rocket (Eruca sativa Mill.) with low nitrate content. J. Food Agr. Environ. 7:405-410.

Fu, Y., H.Y. Li, J. Yu, H. Liu, Z.Y. Cao, N.S. Manukovsky, and H. Liu. 2017. Interaction effects of light intensity and nitrogen concentration on growth, photosynthetic characteristics and quality on lettuce (Lactuca sativa L. var. Youmaicai). Scientia Hort. 214:51-57.

Fukuda, N., M. Miyagi, Y. Suzuki, H. Ikeda, and K. Takayanagi. 1999. Effects of supplemental night lighting and $\mathrm{NO}_{3}^{-}$exclusion on the growth and $\mathrm{NO}_{3}{ }^{-}$concentration in the leaf sap of greenhouse-grown spinach under NFT. J. Jpn. Soc. Hort. Sci. 68:146-151.

Gaudreau, L., J. Charbonneau, L.P. Vezina, and A. Gosselin. 1995. Effects of photoperiod and photosynthetic photon flux on nitrate content and nitrate reductase activity in greenhousegrown lettuce. J. Plant Nutr. 18:437-453.

Gent, M.P.N. 2014. Effect of daily light integral on composition of hydroponic lettuce. HortScience 49:173-179.

Gent, M.P.N. 2016. Effect of irradiance and temperature on composition of spinach. HortScience 51:133-140.

Gürkan, R. and N. Altunay. 2018. Preconcentration and indirect quantification of trace nitrite, nitrate and total nitrite in selected beverage and milk samples using ion-pairing cloud-point extraction with acridine orange. J. Food Compos. Anal. 69:129-139.

He, J., L. Lim, and L. Qin. 2015. Growth irradiance effects on productivity, photosynthesis, nitrate accumulation and assimilation of aeroponically grown Brassica alboglabra. J. Plant Nutr. 38:1022-1035.

Hill, M.J. 1990. Nitrates and nitrites from food and water in relation to human disease, p. 163-193. In: M. Hill (ed.). Nitrates and nitrites in food and water. Woodhead Publishing, Hampshire, UK.

Hord, N. 2011. Dietary nitrates, nitrites, and cardiovascular disease. Curr. Atheroscler. Rep. 13:484-492.

Hsu, J., J. Arcot, and A. Lee. 2009. Nitrate and nitrite quantification from cured meat and vegetables and their estimated dietary intake in Australians. Food Chem. 115:334-339.

Huber, J.L., S.C. Huber, W.H. Campbell, and M.G. Redinbaugh. 1992. Reversible light/dark modulation of spinach leaf nitrate reductase activity involves protein phosphorylation. Arch. Biochem. Biophys. 296:58-65.
Johkan, M., K. Shoji, F. Goto, S. Hahida, and T. Yoshihara. 2012. Effect of green light wavelength and intensity on photomorphogenesis and photosynthesis in Lactuca sativa. Environ. Exp. Bot. 75:128-133.

Lee, J.G., S. Lim, J. Kim, and E.J. Lee. 2017. The mechanism of deterioration of the glucosinolatemyrosynase system in radish roots during cold storage after harvest. Food Chem. 233:60-68.

Lin, K.H., M.Y. Huang, W.D. Huang, M.H. Hsu, Z.W. Yang, and C.M. Yang. 2013. The effects of red, blue, and white light-emitting diodes on the growth, development, and edible quality of hydroponically grown lettuce (Lactuca sativa L. var. Capitata). Scientia Hort. 150:86-91.

Ministerio de Agricultura, Pesca y Alimentación. 2016. Datos estadísticos de productos agrícolas por superficie y producción. 24 Feb. 2017. $<$ https://www.mapa.gob.es/es/agricultura/temas/ default.aspx $>$.

Montgomery, D.C. 2004. Diseño y análisis de experimentos. 2nd ed. John Wiley \& Sons, Inc., New York.

Nájera, C., J.L. Guil-Guerrero, L. Jarquín, J. Álvaro, and M. Urrestarazu. 2018. LEDenhanced dietary and organoleptic qualities in postharvest tomato fruit. Postharvest Biol. Technol. 145:151-156.

Nicola, S., J. Hoeberechts, and E. Fontana. 2007. Ebb-and-flow and floating systems to grow leafy vegetables: A review for rocket, corn salad, garden cress and purslane. Acta Hort. 747:585-592.

Novo, A.A.C., J.F. Medeiros, C.H.E. de Souza, P.R.G. Pereira, H.E.P. Martinez, P.C.R. Fontes, and N.N. Cometti. 2008. Infuência do sombreamento sobre o crescimento e teores de nitrato em hortaliças folhosas em hidroponia. Hort. Bras. 22:S3761-S3766.

Ohashi, K.K., M. Takase, N. Kon, K. Fujiwara, and K. Kurata. 2007. Effect of light quality on growth and vegetable quality in leaf lettuce, spinach and komatsuna. Environ. Control Biol. 45:189-198.

Proietti, S., S. Moscatello, G. Colla, and Y. Battistelli. 2004. The effect of growing spinach (Spinacia oleracea L.) at low light intensities on the amounts of oxalate, ascorbate and nitrate in their leaves. J. Hort. Sci. Biotechnol. 79:606-609.

Riens, B. and H. Walter. 1991. Decrease of nitrate reductase activity in spinach leaves during a light-dark transition. Plant Physiol. 98:573577.

Roorda, E.J.P. 1984. Nitrate in vegetables under protected cultivation. Acta Hort. 145:251-256.

Samuolienè, G., R. Sirtautas, A. Brazaitytè, J. Sakalauskaite, S. Sakalauskiene, and $\mathrm{P}$. Duchovskis. 2011. The impact of red and blue light-emitting diode illumination on radish physiological indices. Cent. Eur. J. Biol. 6:821-828.

Samuolienè, G., A. Urbonavičiūtè, P. Duchovskis, Z. Bliznikas, P. Vitta, and A. Žukauskas. 2009. Decrease in nitrate concentration in leafy vegetables under a solid-state illuminator. HortScience 44:1857-1860.

Sanchez, C.A., K.S. Crump, R.I. Krieger, N.R. Khandaker, and J.P. Gibbs. 2005. Perchlorate and nitrate in leafy vegetables of North America. Environ. Sci. Technol. 39:9391-9397.

Santamaria, P. 2006. Nitrate in vegetables: Toxicity, content, intake and EC regulation. J. Sci. Food Agr. 86:10-17.

Seifu, Y.W. 2017. Nitrate content in minimally processed lettuce (Lactuca sativa L.) as affected by fluorescent light exposure during storage. J. Plant Biochem. Physiol. 5:1-5. 
Sonneveld, C. and N. Straver. 1994. Nutrient solutions for vegetables and flowers grown in water or substrates. 10th ed. Naaldwijk, the Netherlands.

Statgraphics Centurion. 2018. Statgraphics Net for Windows 7. <https://www.statgraphics.net/ descargas-centurion-xvii/>.

Steingröver, E., P. Ratering, and J. Siesling. 1986. Daily changes in uptake, reduction and storage of nitrate in spinach grown at low light intensity. Physiol. Plant. 66:550-556.
Urrestarazu, M., C. Nájera, and M.M. Gea. 2016. Effect of the spectral quality and intensity of light-emitting diodes on several horticultural crops. HortScience 51:268-271.

Urrestarazu, M., A. Postigo, M.C. Salas, A. Sánchez, and G. Carrasco. 1998. Nitrate accumulation reduction using chloride in the nutrient solution on lettuce growing by NFT in semiarid climate conditions. J. Plant Nutr. 21:1705-1714.

Wojciechowska, R., O. Dlugosz-Grochowska, A. Kolton, and M. Zupnik. 2015. Effects of LED supplemental lighting on yield and some quality parameters of lamb's lettuce grown in two winter cycles. Scientia Hort. 187:80 86.

Yang, J.H. and D.H. Park. 2015. A study on growth of the plant depends on PPFD and wavelength of LED lighting module. J. Korean Soc. Mechan. Tech. 17:31-37.

Zhang, T., Y. Shi, F. Piao, and Z. Sun. 2018. Effects of different LED sources on the growth and nitrogen metabolism of lettuce. Plant Cell 134:231-240. 